\title{
Escherichia coli O157:H7 in food with health-related risks
}

\author{
Rabya A. Lahmer ${ }^{1}$, Prysor A. Williams ${ }^{2}$ Davey L. Jones²
}

${ }^{1}$ Department of Food Science and Technology, Faculty of Agriculture, University of Tripoli. Tripoli, Libya.

ID orcid.org/0000-0003-4698-7464

${ }^{2}$ School of Environment, Natural Resources \& Geography, College of Natural Sciences, Bangor University, UK, LL57 2UWCC

ID orcid.org/0000-0001-6477-7407

ID orcid.org/0000-0002-1482-4209

*Corresponding author: rabyalahmer@yahoo.co.uk

\section{Abstract}

E. coli O157:H7 has been implicated in many cases of food contamination across the world, in both the beef and poultry industries, with approximately 1,000 E. coli O157 cases reported in

\section{Health Sciences}


UK each year. This includes 100 cases of haemolytic uraemic syndrome, a serious illness that can cause acute renal failure. Indeed, E. coli O157:H7 infections are of particular concern due to the potential severity of symptoms. An estimated 73,500 cases of illness, 2000 hospitalisations and 60 deaths occur each year in the USA due to E. coli $\mathrm{O} 157$ infection, costing approximately $\$ 1$ billion a year in medical costs and lost productivity E. coli O157:H7 is regarded as being more transmissible than other $E$. coli serotypes for a number of reasons, including its increased tolerance to acid, which allows it to easily survive the acidic conditions of the stomach. This bacterium also produces Shiga toxins, which are heat stable, and therefore unaffected by conventional pasteurization methods. Small doses of fewer than 10 cells may lead to infection. Collectively, these factors make the control of E. coli O157:H7 an important issue in recent times for the food sector. Many preventative measures have been introduced and targeted at all stages of the food chain, from the farm, to the slaughterhouse, and to the preparation of food at home.

Keywords: Contamination, food safety, Pathogen, microbiological quality.

\section{Introduction}

The increasing number and severity of food poisoning outbreaks on a global scale have considerably increased public awareness of food safety (Food Standards Agency, 2012). Well publicised cases of Escherichia coli (E. coli) serotype O157:H7 infections in particular are of concern due to the potential severity of symptoms (HPA, 2013). Although E. coli O157:H7 was only first recognized as a cause of foodborne illness just over 30 years ago (Forsythe, 2010), it has been implicated in sporadic cases and large outbreaks of haemorrhagic colitis and fatal haemolytic uremic syndrome (Karmali et al., 2010). This serotype is regarded as being more transmissible than other $E$. coli serotypes due to a number of reasons, including its increased tolerance to acid, which allows it to easily survive the acid conditions of the stomach. This bacterium also produces Shiga toxins, which are heat stable, and therefore unaffected by conventional pasteurization methods (Rasooly and Do, 2010). Small doses of fewer than 10 cells

\section{Health Sciences}


may lead to infection (Forsythe, 2010). Collectively, these factors make the control of E. coli O157:H7 an important issue in recent times for the food sector.

The main causes for concern and product recalls associated with $E$. coli O157:H7 are meat products (Mor-Mur and Yuste, 2010). In particular, cattle and sheep are major reservoirs for this pathogen (Nastasijevicl et al., 2008; Hutchinson et al., 2005) and contamination of carcasses and food products by animal faeces can lead to transmission of foodborne pathogens to consumers (Oliver et al., 2008). Numerous interventions to be applied at the farm level have been investigated over the past 20 years, but most have proven to be ineffective and/or impractical (Soon et al., 2011). Furthermore, the conflict between demands for minimally processed foods and the modern requirement of long shelf-life and food safety is an issue for the food industry. This has led to interest in the use of natural antimicrobial products.

\section{Clinical aspects of $E$. coli $\mathrm{O} 157: \mathrm{H7}$}

Infection with E. coli O157:H7 is asymptomatic in a large proportion of cases, but can also engender a wide range of clinical symptoms ranging from non-bloody diarrhoea to hemorrhagic colitis and other life-threatening complications. Serious health effects arising from infection can involve acute renal failure caused by haemolytic uraemic syndrome (HUS) (Rahal et al., 2012), and neurological problems in the form of thrombotic thrombocytopaenic purpura (TTP) (Duffy et al., 2006; Thomas and Elliott, 2013). Other rare complications include pancreatitis, diabetes mellitus, and pleural and pericardial effusions (Mead \& Griffin, 1998). Occasionally, patients infected with E. coli O157:H7 suffer damage to their central nervous system as TTP, which typically includes seizures arising from hypertensive encephalopathy. Untreated TTP can have a mortality rate as high as $95 \%$. Symptoms may include thrombocytopenia, fever, renal insufficiency, neurological deficit, microangiopathic haemolytic anaemia, headache, fatigue/malaise, altered mental status, and hemiplegia (Rahal et al., 2012).

\section{Epidemiology}

Vero cytotoxin_producing Escherichia coli VTEC has become the most frequently reported cause of bacteraemia in England, Wales

\section{Health Sciences}


and Northern Ireland (HPA, 2007). A report from HPA (2013) (Figure 2.1) suggests almost a $100 \%$ increase, from 595 to 1182 , in the annual totals of VTEC infections in England \& Wales between 2002 and 2011. To date, many parts of the world have witnessed outbreaks of VTEC infections involving serotype O157 (Duffy et al., 2006). Infection rates differ widely between geographical regions. In Europe, Scotland possesses the highest infection rates with approximately 4 cases per 100,000 (Duffy et al., 2006), while in Northern Europe infection rates are very low (e.g. 0.04 per 100,000 in Norway and Finland). In North America, the infection rate for E. coli O157:H7 was 0.9 per 100,000 in 2004. In Asia, Japan has experienced the most problems related to E. coli O157:H7 (2.74 per 100,000 averaged between 1999 and 2004; Duffy et al., 2006). An estimated 73,500 cases of illness, 2000 hospitalisations and 60 deaths occur each year in the USA due to E. coli O157 infection (Mead et al., 1999), costing approximately $\$ 1$ billion a year in medical costs and lost productivity (Wilks et al., 2005). E. coli O157:H7 cases in England and Wales have fluctuated somewhat over the last ten years (HPA, 2012; Figure 2.1).

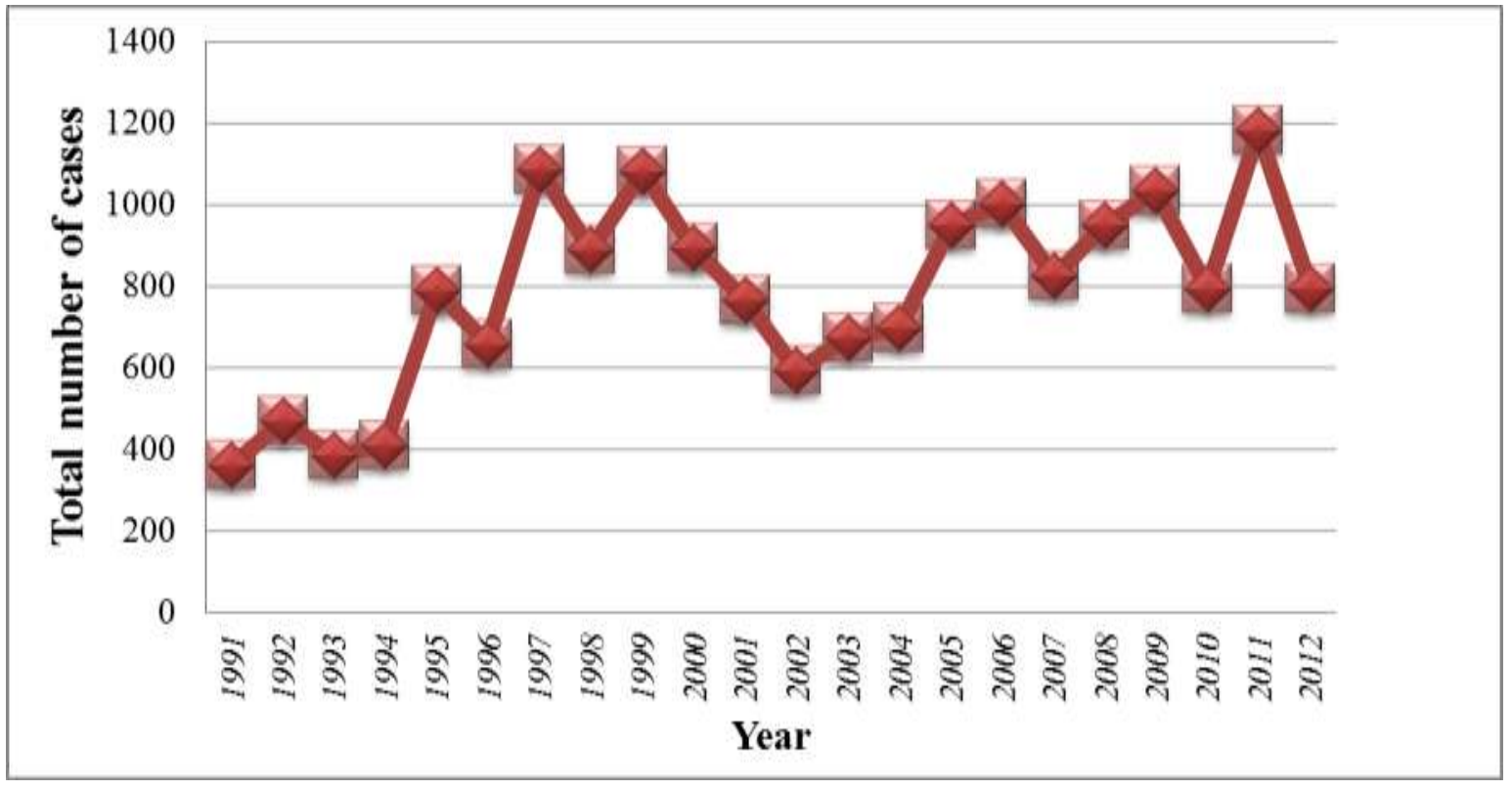

Figure 2. 1. Annual totals of VTEC (E. coli O157:H7) infections in England \& Wales (HPA, August 2013). 


\section{Sources of infection}

E. coli O157:H7 infections have been associated with a variety of sources and routes (Duffy et al., 2006). Apart from animal-to-person and person-to-person transmission, consumption of E. coli O157:H7contaminated food, particularly in public places such as day care centres, is an important mode of transmission that has attracted much attention in recent years (Chang \& Fang, 2007; Duffy, et al., 2006; EFS, 2007; Liu et al., 2009; Meyer-Broseta et al., 2001). To date, research has investigated survival of the pathogen in a wide range of foods, including meat and meat products (Hwang et al., 2009; Rhoades et al., 2009), dairy products (Voitoux et al., 2002), lettuce (Koseki et al., 2004), apples (Du et al., 2003), tomatoes (Eribo \& Ashenafi, 2003), chocolate and other confectionery (Baylis et al., 2004), and drinking water (Schets et al., 2005).

Farm livestock, particularly ruminants like cattle, sheep, and goats, are regarded as the primary reservoirs for VTEC (Heuvelink et al., 1998). Numerous studies have investigated E. coli O157:H7 prevalence, transmission, survival and control in cattle and beef (Duffy et al., 2006; Rhoades et al., 2009). Among others, the review by Rhoades et al. (2009) discussed factors that influence the prevalence of three important pathogens, VTEC E. coli, Salmonella enterica, and Listeria monocytogenes in the whole process of meat production. It is estimated that the most severe cases of food-borne disease have been reported to be attributable to various foodstuffs containing beef. For instance, Adak et al. (2005) indicated that in England and Wales, 7\% of the 1.7 million cases of food-borne disease in the period 1996-2000, including 67 deaths, were associated with beef. In the Netherlands, undercooked ground beef and raw milk have most often been implicated in food-borne infections (Heuvelink et al., 1998). Different countries may present different situations of food-borne disease, depending on factors such as the pathogen load in the beef products consumed and the cooking and consumption habits of the country concerned (Rhoades et al., 2009). Products such as lightly-cooked burgers may be eaten more frequently in the USA, while people in France and the Netherlands consume more steak tartare than people in the UK and Greece. 


\section{Meat}

E. coli $\mathrm{O} 157: \mathrm{H7}$ exists as a normal coloniser of the gastrointestinal tract of cattle (Heuvelink et al., 1998; Nastasijevic et al., 2009). A number of studies have focussed on the prevalence of $E$. coli in the meat chain starting from the farm, the slaughterhouse, to the final, ready-to-eat products (Nastasijevic et al., 2009, Rhoades et al., 2009). The spread of E. coli O157:H7 has been identified in farm housing and faeces (Jones, 1999) and the pathogen is known to survive for considerable periods in faeces and slurry (Avery et al., 2004). This bacterium may readily leach from sheep and cattle faeces during rainstorm events thus leading to further infections (Williams et al., 2005). Pigs and poultry can also be a source of O157 VTEC strain. Heuvelink et al. (1999) found that E. coli O157:H7 were isolated from $1.4 \%$ of 145 pigs and from $1.3 \%$ of 459 pooled faecal samples from turkey flocks but was negative in faecal samples from chicken flocks. In a similar study, Kijima-Tanaka et al. (2005) isolated shiga toxinproducing Escherichia coli (STEC) from 23\% of 62 bovine faecal samples and $14 \%$ of 25 swine samples and again there was no isolation from chicken samples. A Korean study by Jo et al. (2004) reported a higher prevalence of $E$. coli O157:H7 in cattle than in pigs $(8.4 \%$ versus $0.3 \%)$ and none in chicken. At slaughter, transmission of E. coli from faecal material and hides to carcasses varies from $4.5 \%$ to $56 \%$ and from $1.1 \%$ to $43.4 \%$ respectively, which poses a great threat for the contamination of raw meat with this pathogen (Nastasijevic et al., 2009). In addition, contamination may occur during the dressing, skinning and evisceration phases (Nastasijevic et al., 2009). Reinstein et al. (2009) examined the prevalence of E. coli O157:H7 in organically and conventionally raised beef cattle at slaughter and found $14.8 \%$ and $14.2 \%$ positives, respectively. An Irish study recovered E. coli O157 from $2.4 \%$ of beef trimmings samples, $3.0 \%$ of beef carcasses and $3.0 \%$ of head meat samples (Carney et al., 2006). The probability of E. coli O157:H7 spreading during the mincing process may be highest in the meat chain (Hawker et al., 2001). One carcass contaminated with E. coli O157:H7 may quickly spread the bacterium across the whole batch of minced meat from uninfected cows. Cagney et al. (2004) detected E. coli O157:H7 in 2.8\% of minced beef and beef burgers, both frozen and fresh, in the Republic of Ireland. 
Magwira et al. (2005) investigated 400 meat samples (134 meat cubes, 133 minced meats, 133 fresh sausages) collected from 15 supermarkets and butcheries in Botswana and found prevalence rates of E. coli O157:H7 were $5.2 \%$ in meat cube samples, $3.8 \%$ in minced meat samples, and $2.3 \%$ in fresh sausages. In South Africa, the prevalence of E. coli O157:H7 was identified on selected meat and meat products (45 samples each of biltong, cold meat, mincemeat, and polony) (Abong'o \& Momba 2009). Strains of E. coli O157:H7 were isolated by enrichment culture and confirmed by polymerase chain reaction (PCR). Also investigated were the arteriogram profiles of the E. coli O157:H7 isolates. Five (2.8\%) out of 180 meat and meat products examined were positive for E. coli O157:H7. A parallel study in Switzerland (Fantelli \& Stephan, 2001) was conducted on minced meat (beef and pork) samples to test for the presence of STEC. STEC was isolated from $2.3 \%$ minced beef samples and $1 \%$ minced pork samples.

\section{Dairy products}

Outbreaks of E coli O157:H7 illness have been found to be linked with consumption of raw milk and cheeses made from unpasteurized milk (Elhadiay and Mohammed, 2012; VernozyRozand, 2005). In 1999, more than $11 \%$ of the total number of E. coli O157:H7 infections in England and Wales were due to unpasteurized milk and dairy product (CDSC, 2000, cited in Vernozy-Rozand, 2005); most probably due to faecal contamination during milking (Hussein \& Sakuma, 2005). Conedera et al. (2004) noted that although the prevalence of VTEC O157 in raw milk and cheese is low, the organism appears to be able to survive the various stages of the cheese-making process. They found that the heat treatment of milk at the beginning stages of cheese production is usually not sufficient to kill the contaminated vegetative bacteria which can later survive the manufacturing and curing procedures. For example, $E$. coli O157:H7 was found to survive during the manufacturing process of soft Hispanic-type cheese (Kasrazadeh \& Genigeorgis, 1995). E. coli O157:H7 is characterized by its ability to survive in acidic environments (e.g. in cheddar cheese after a curing period of more than two months; Reitsma \& Henning, 1996). Furthermore,

\section{Health Sciences}


fermented dairy products made from raw milk contaminated with $E$. coli $\mathrm{O} 157$ can pose a risk to human health (Vernozy-Rozand et al., 2005). Marek et al. (2004) examined the survival of E. coli O157:H7 in pasteurized and unpasteurized Cheddar cheese whey. Five strains of E. coli O157:H7 were used for the study and were inoculated into 100 $\mathrm{ml}$ of fresh, pasteurized or unpasteurized Cheddar cheese whey at $10^{5}$ or $10^{2} \mathrm{CFU} \mathrm{ml}-1$, and stored at varying temperatures. Results showed that survival of E. coli O157:H7 was significantly higher in the pasteurized whey compared to that in the unpasteurized samples at all storage temperatures. Stringent sanitary practices should therefore be undertaken, particularly during the storage and handling of whey and use of pasteurized milk for cheese manufacture.

\section{Vegetables and fruits}

In the past ten years, an increased number of E. coli O157:H7-related outbreaks have been associated with fresh produce such as lettuce, cantaloupe, and alfalfa sprouts (Doyle \& Erickson, 2008; Silagyi et al., 2009; Pathanibul et al., 2009). This growing tendency could be due to increased consumptions of potentially risky fresh-cut pre-packaged products (Doyle \& Erickson, 2008). Four separate outbreaks of foodborne E. coli O157 infections were recorded in USA in 2006 (Doyle \& Erickson, 2008). Common vehicles of the disease noted were fruits and vegetables such as green-based salads, potatoes, lettuce, unspecified fruits, and sprouts (Doyle \& Erickson, 2008). Among the reported outbreaks, lettuce was the single most frequently mentioned produce (Ackers et al., 1998; López-Gálvez et al., 2009). Ackers et al. (1998) found 70\% of patients in 40 Montana residents were infected with E. coli O157:H7 due to the consumption of purchased leaf lettuce. In addition, Eribo and Ashenafi (2003) demonstrated that E. coli O157:H7 could be found in tomato and processed tomato products as well as products containing vinegar. $E$. coli O157:H7 showed the ability to grow during germination a sprouting of alfalfa (Castro-Rosas \& Escartin, 2008) and in acidic foods such as fermented Spanish-style table olives (Spyropoulou et al., 2001). 


\section{Resilience of E. coli O15:H7 to environmental conditions}

Environmental conditions such as temperature, $\mathrm{pH}$ value, water activity, and sodium chloride have important implications in the survival and growth rates of E. coli O157:H7 in foodstuffs. The bacterium is known to have a typical resistance to heat (Kaur et al., 1998). It can proliferate at a temperature range of $8-44.5^{\circ} \mathrm{C}$, with the optimal temperature for growth at $37^{\circ} \mathrm{C}$ (Edwards \& Fung, 2006). Cooking beef thoroughly to $71{ }^{\circ} \mathrm{C}$ is effective in eliminating the organism (Doyle \& Schoeni, 1984); although slow cooking of meats may not eradicate the organism as well as rapid heating (Edwards \& Fung, 2006; Kaur et al., 1998). Regardless of $\mathrm{pH}$ and water activity, survival of $E$. coli was found to be better at $5^{\circ} \mathrm{C}$ than at 20 or $30{ }^{\circ} \mathrm{C}$ in tryptic soy broth (TSB) (Rocelle et al., 1996). Moreover, E. coli was found to survive but not grow during fermentation, drying, or subsequent storage at $4{ }^{\circ} \mathrm{C}$ for 2 months (Glass et al., 1992). The heatresistant property of $E$. coli $\mathrm{O} 157: \mathrm{H} 7$ is relative as it can be influenced by many other environmental factors, including growth phase, the amount of heat applied, the rate of heating and the water activity (Kaur et al., 1998). For instance, at $30^{\circ} \mathrm{C}$, inhibition of growth of $E$. coli O157:H7 in TSB was enhanced by reduction of the water activity (Rocelle et al., 1996) as well as increase of sodium chloride concentration (Jordan and Davies, 2001).

Much evidence has shown that $\mathrm{pH}$ value plays a primary role in the growth rates of E. coli O157:H7. For instance, growth rates are similar at moderate $\mathrm{pH}$ values $(\mathrm{pH}$ 5.5-7.5), but decrease significantly at lower $\mathrm{pH}$ values (Edwards \& Fung, 2006). Yet, Benjamin \& Datta (1995) found the organism to be acid tolerant under the optimal temperature $\left(37^{\circ} \mathrm{C}\right)$, surviving at $\mathrm{pH} 2.5$ for up to $7 \mathrm{~h}$. The pathogen is capable of acid-adaption and adapted cells have shown increased survival in shredded dry salami and apple cider (Leyer et al., 1995). E. coli O157:H7 has been reported to survive for months in acidic foods, such as fermented sausages (CDC, 1995) and apple cider and apple juice (Du et al., 2003); even though products such as fermented sausage may also lead to water stress in bacteria. The resilience of the organism to a combination of factors such as temperature, $\mathrm{pH}$, water activity and sodium chloride can all contribute to the survival and growth of E. coli O157:H7 in foodstuffs. Its ability to withstand low 
$\mathrm{pH}$ environments is also of course crucial during passage through the gastro-intestinal tract of livestock and humans.

E. coli O157 can survive and grow in both aerobic and anaerobic conditions as well as modified atmospheres used for food packaging (Bromberg et al., 1998). As a facultative anaerobe, the heat resistance of this pathogen can vary between anaerobic and aerobic environments. For instance, it has been documented that there was little influence on the capability of E. coli O157:H7 under anaerobic conditions, but when aerobically-situated, the pathogen showed reduced heat-resistance (Bromberg et al., 1998). Consequently, this has important implications in food packing. Therefore, there may be increased risk of E. coli O157:H7 surviving during heating treatments of foodstuffs that are packed under vacuum or reduced oxygen atmospheres (George et al., 1998).

\section{Control of E. coli O157:H7}

The increase in number of food-borne pathogenic infections has generated considerable efforts in the control of organism such as $E$. coli $\mathrm{O} 157$ in food. Many preventative measures have been introduced and targeted at all stages of the food chain, from the farm, to the slaughterhouse, and to the preparation of food at home (VernozyRozand et al., 2002; Zhu et al., 2009).

Although total elimination of E. coli O157:H7 carriage in livestock appears unlikely, pathogen transmission can be reduced through a number of farm management practices, such as to forbidding farmers from applying slurry and animal manure to vegetables and fruit plants (Jones, 1999). Good hygiene practices such as careful preparation and cooking of food and interventions such as pasteurization, organic acid washes, and stream vacuuming, as well as the use of antimicrobial solutions (e.g. dilute lactic acid, trisodium phosphate and chlorine) can be effective means to eliminate E. coli O157:H7 from food (Marshall et al., 2005; Rhoades et al., 2009; Vernozy-Rozand et al., 2002). For instance, to prevent minced meat from contamination with E. coli O157:H7 during the mincing process, cooking at a high temperature can destroy E. coli O157:H7 cells (Abong'o \& Momba, 2009). To prevent contamination of apple cider, it is suggested to wash and brush apples and preserve the cider with sodium benzoate (Zhao et al., 1993; cited in Chapman, 1995) or aqueous commercial cleaner (Kenney \& Beuchat, 2002). To reduce 
the number of VETC on salad vegetables, storing salad vegetables at $4{ }^{\circ} \mathrm{C}$ can be an effective means (Abdul-Raouf et al., 1993).

In recent years, advanced technologies have also been explored in the produce industry to reduce E. coli O157:H7and other pathogens as well as to maintain the sensory quality of the produce itself (Arqués et al., 2015). In 2007, Muthukumarasamy and Holley investigated the effect of probiotic incorporation in dry fermented sausages before and after they were micro-encapsulated on the viability of E. coli O157:H7. The researchers found that there is a reduction in the viability of E. coli O157:H7. On the other hand, they reported that micro-encapsulation increased survival of probiotic strains, maintain sensory properties but reduced their inhibitory action against E. coli O157:H7. One study by Selma et al. (2008) showed the combined application of gaseous ozone and hot water could effectively control microbial growth in cantaloupe melon as well as maintain its initial sensory quality such as aroma and texture. However, this study failed to point out specific action of ozone in inactivating E. coli O157:H7. Mahmoud (2010) explicitly demonstrated the efficacy of X-ray on inoculated E. coli O157:H7 (also including L. monocytogences, S. enterica and S. flexneri) on shredded iceberg lettuce. By treating iceberg lettuce with 1.0 and 2.0 KGy X-ray, the study detected significant reductions of E. coli O157:H7 population in both conditions. This approach also showed its promising application because the sensory quality (i.e., visual colour) of leaves was not adversely affected during subsequent storage. Recently, the development of multistrain probiotic dairy products with good technological properties, has gained increased interest as protective cultures against infections (Arqués et al., 2015).Although controlling E. coli O157:H7 in food through thermal treatment, chemical destruction and preventative interventions have showed some due efficacy, some studies also report negative findings. For instance, organic acids such as lactic acid and citric acid were reported ineffective in controlling E. coli O157:H7 in beef burgers, even when combined with freezing at $-20{ }^{\circ} \mathrm{C}$ for 2 hours (Bolton et al., 2002). Another study on traditional Iranian barbecued chicken (TIBC) reported that although essential oils of oregano and nutmeg showed effectiveness in inhibiting the growth of E. coli O157 $\mathrm{H}: 7$ in a broth culture system, they reported no inhibitory effect 
against this pathogen in ready-to-cook TIBC, suggesting that in vitro investigation may not necessarily be applicable to food conditions (Shekarforoush et al., 2007). Although the importance of temperature control and protective packaging has been emphasized in reducing pathogen growth on raw meat, inoculated E. coli O157:H7 strain NCTC 12900 could still increase when lamb chops were kept at $4{ }^{\circ} \mathrm{C}$ for 12 days (Barrera et al., 2007).

\section{Conclusion}

Escherichia coli $\mathrm{O} 157$ is an important food-borne bacterial pathogen closely associated with many severe human illnesses such as haemolytic uremic syndrome. Many of the intervention measures described are still effectively at experimental stage and are unlikely to be widely implemented in the foreseeable future due to a lack of commercial viability, geographical differences in the regulatory framework, or a lack of acceptance by consumers. Elevated public concerns about the adverse consequences of chemically synthesized preservatives used in food industry have diverted research to the application of natural antimicrobials to inhibit E. coli O157:H7 growth and activity. 


\section{References}

Abdul-Raouf, U.M., Beuchat, L.R. \& Ammar, M.S. (1993). Survival and growth of Escherichia coli O157:H7 on salad vegetables. Applied and Environmental Microbiology 59, 19992006.

Abong'o, B.O. \& Momba, M.N.B. (2009). Prevalence and characterization of Escherichia coli O157:H7 isolates from meat and meat products sold in amathole district, Eastern Cape province of South Africa. Food Microbiology 26, 173-176.

Ackers, M.L., Mahon, B.E., Leahy, E., Goode, B., Damrow, T., Hayes, P.S., Bibb, W.F., Rice, D.H., Barrett, T.J., Hutwagner, L., Griffin, P.M. \& Slutsker, L. (1998). An outbreak of Escherichia coli O157:H7 infections associated with leaf lettuce consumption. Journal of Infectious Diseases 177, 1588-1593.

Adak, G.K., Meakins, S.M., Yip, H., Lopman, B.A. \& O'Brien, S.J. (2005). Disease risks from foods, England and Wales, 1996-2000. Emerging Infectious Diseases 11, 365-372.

Arqués, J. L., Rodríguez, E., Langa, S. Landete, JM. \& Medina, M. (2015). Antimicrobial Activity of Lactic Acid Bacteria in Dairy Products and Gut: Effect on Pathogens. BioMed Research International Volume 2015, Article ID 584183, 9 pages http://dx.doi.org/10.1155/2015/584183

\section{Health Sciences}


Avery, L.M., Killham, K. \& Jones, D.L. (2005). Survival of E. coli O157:H7 in organic wastes destined for land application. Journal of Applied Microbiology 98, 814-822.

Barrera, O., Rodriguez-Calleja, J.M., Santos, J.A., Otero, A. \& Garcia-Lopez, M. (2007). Effect of different storage conditions on E. coli $\mathrm{O} 157: \mathrm{H7}$ and the indigenous bacterial microflora on lamb meat. International Journal of Food Microbiology 115, 244-251.

Baylis, C.L., MacPhee, S., Robinson, A.J., Griffiths, R., Lilley, K. \& Betts, R.P. (2004). Survival of Escherichia coli O157:H7, O111: H- and O26:H11 in artificially contaminated chocolate and confectionery products. International Journal of Food Microbiology 96, 35-48.

Benjamin, M.M. \& Datta, A.R. (1995). Acid tolerance of enterohemorrhagic Escherichia coli. Applied and Environmental Microbiology 61.1669-1672.

Bolton, D.J., Catarame, T., Byrne, C., Sheridan, J.J., McDowell, D.A. \& Blair, I.S. (2002). The ineffectiveness of organic acids, freezing and pulsed electric fields to control Escherichia coli O157:H7 in beef burgers. Letters in Applied Microbiology 34, 139-143.

Bromberg, R., George, S.M. \& Peck, M.W. (1998). Oxygen sensitivity of heated cells of Escherichia coli O157:H7. Journal of Applied Microbiology 85, 231-237.

\section{Health Sciences}


Cagney, C., Crowley, H., Duffy, G., Sheridan, J.J., O'Brien, S., Carney, E., Anderson, W., McDowell, D.A., Blair, I.S., Bishop, R.H. (2004). Prevalence and numbers of Escherichia coli O157:H7 in minced beef and beef burgers from butcher shops and supermarkets in the Republic of Ireland. Food Microbiology 21, 203-212.

Carney, E., O'Brien, S.B., Sheridan, J.J., McDowell, D.A., Blair, I.S. \& Duffy, G. (2006). Prevalence and level of Escherichia coli $\mathrm{O} 157$ on beef trimmings, carcasses and boned head meat at a beef slaughter plant. Food Microbiology 23, 52-59.

Castro-Rosas, J. \& Escartin, E.F., (2000). Survival and growth of Vibrio cholerae O1, Salmonella typhi, and Escherichia coli O157:H7 in alfalfa sprouts. Journal of Food Science 65, 162-165.

Centers for Disease Control. (1995). Escherichia coli O157:H7 outbreak linked to commercially distributed dry-cured salami: Washington and California, 1994. Morbidity and Mortality Weekly Report 44, 157-160.

Chang, J. \& Fang, T.J. (2007). Survival of Escherichia coli O157:H7 and Salmonella enterica serovars Typhimurium in iceberg lettuce and the antimicrobial effect of rice vinegar against $E$. coli O157:H7. Food Microbiology 24, 745-751.

Chapman, P.A. (1995). Verocytotoxin-producing Escherichia-coli: An overview with emphasis on the

\section{Health Sciences}


epidemiology and prospects for control of E. coli O157. Food Control 6, 187-193.

Doyle, M.P. \& Erickson, M.C. (2008). The problems with fresh produce: an overview. Journal of Applied Microbiology 105, 317-326.

Doyle, M.P. \& Schoeni, J.L. (1984). Survival and growth characteristics of Escherichia. coli associated with hemorrhagic colitis. Applied and Environmental Microbiology 48, 855-856.

Du, J., Han, Y. \& Linton, R.H. (2003). Efficacy of chlorine dioxide gas in reducing Escherichia coli O157:H7 on apple surfaces. Food Microbiology 20, 583-591.

Duffy, G., Cummins, E., Nally, P., O'Brien, S. \& Butler, F. (2006). A review of quantitative microbial risk assessment in the management of Escherichia coli O157:H7 on beef. Meat Science 74, 76-88.

Edwards, J.R. \& Fung, D.Y.C. (2006). Prevention and decontamination of Escherichia coli O157:H7 on raw beef carcasses in commercial beef abattoirs. Journal of Rapid Methods and Automation in Microbiology 14, 1-95.

Elhadiay, M., \& Mohammed, M.A. (2012). Shiga toxinproducing Escherichia coli from raw milk cheese in Egypt: Prevalence, molecular characterization and survival to stress conditions. Letters in Applied Microbiology 56, 120-127.

\section{Health Sciences}


Eribo, B. \& Ashenafi, M. (2003). Behavior of Escherichia coli O157:H7 in tomato and processed tomato products. Food Research International 36, 823-830.

European Food Safety Authority (2007). Monitoring of verotoxigenic Escherichia coli (VTEC) and identification of human pathogenic VTEC types; Scientific opinion of the panel on biological hazards. The European Food Safety Authority Journal $579,1-61$.

Fantelli, K. \& Stephan, R. (2001). Prevalence and characteristics of Shigatoxin-producing Escherichia coli and Listeria monocytogenes strains isolated from minced meat in Switzerland. International Journal of Food Microbiology 70, 63-69.

Forsythe, S. (2010). The microbiology of safe food. 2nd Ed. Wiley-Blackwell, UK.

George, S.M., Richardson, L.C.C., Pol, I.E. \& Peck, M.W. (1998). Effect of oxygen concentration and redox potential on recovery of sublethally heat-damaged cells of Escherichia coli O157:H7, Salmonella enteritidis and Listeria monocytogenes. Journal of Applied Microbiology 84, 903-909.

Glass, K.A., Loeffelholz, J.M., Ford, J.P. \& Doyle, M.P. (1992). Fate of Escherichia coli O157:H7 as affected by $\mathrm{pH}$ or sodium chloride and in fermented, dry sausage. Applied and Environmental Microbiology 58, 2513-2516.

\section{Health Sciences}


Goy, R.C., de Britto, D. \& Assis, O.B.G. (2009). A review of the antimicrobial activity of chitosan. Polimeros:Ciẹncia $e$ Tecnologia 19, 241-247.

Hawker, J., Begg, N.B., Blair, B., Reintjes R. \& Weinberg, J. (2001). Communicable Disease Control Handbook. Wiley Blackwell. Oxford: UK.

Health Protection Agency (2013). Vero cytotoxinprotoxin-producing Escherichia coli (VTEC).

Health Protection Agency. (2007). Surveillance of healthcare associated infections. http://www.hpa.org.uk/webc/HPAwebFile/HPAweb_C/11969421694 $\underline{46}$ (accessed 3/05/11).

Health Protection Agency. (2010). Escherichia coli bacteraemia in England, Wales, and Northern Ireland, 2004 to 2008.

http://www.hpa.org.uk/webc/HPAwebFile/HPAweb_C/12532054640 $\underline{89}$ (accessed 8/1/13).

Health Protection Agency. (2012). Epidemiological data on VTEC in England \& Wales. http:/ / www.hpa.org.uk/web/HPAweb\&HPAwebStandard/ HPAweb_C/1249113624846 (accessed 8/1/13).

Heuvelink, A.E., van den Biggelaar, F.L.A.M., de Boer, E., Herbes, R.G., Melchers, W.J.G., Huis In T Veld, J.H.J. \& Monnens, L.A.H. (1998). Isolation and characterization of

\section{Health Sciences}


verocytotoxin-producing Escherichia coli O157 strains from Dutch cattle and sheep. Journal of Clinical Microbiology 36, 878882.

Heuvelink, A.E., Zwartkruis-Nahuis, J.T.M., van den Biggelaar, F.L.A.M., van Leeuwen, W.J. \& de Boer, E. (1999). Isolation and characterization of verocytotoxin-producing Escherichia coli O157 from slaughter pigs and poultry. International Journal of Food Microbiology 52, 67-75.

http://www.hpa.org.uk/Topics/InfectiousDiseases/Infe ctionsAZ/EscherichiaColiO157/ (accessed 22/015/13).

Hussein, H.S. \& Sakuma, T. (2005). Prevalence of Shiga toxin-producing Escherichia coli in dairy cattle and their products. Journal of Dairy Science 88, 450-465.

Hutchinson, J.P., Chernery, T.E.A., Smith, R.P., Lynch, K., \& Pritchard, G.C., (2005). Verocytotoxin-producing and attaching and effacing activity of Escherichia coli isolated from diseased farm livestock. Veterinary Record 186, 536-545.

Hwang, C., Porto-Fett, A.C.S., Juneja, V.K., Ingham, S.C., Ingham, B.H. \& Luchansky, J.B. (2009). Modeling the survival of Escherichia coli O157:H7, Listeria monocytogenes, and Salmonella Typhimurium during fermentation, drying, and storage of soudjouk-style fermented sausage. International Journal of Food Microbiology 129, 244-252.

\section{Health Sciences}


Jo, M.Y., Kim, J.H., Lim, J.H., Kang, M.Y., Koh, H.B., Park, Y.H., Yoon, D.Y., Chae, J.S., Eo, S.K. \& Lee, J.H. (2004). Prevalence and characteristics of Escherichia coli O157 from major food animals in Korea. International Journal of Food Microbiology 95, 41-49.

Jordan, K.N., and Davies, K.W. (2001). Sodium chloride enhances recovery and growth of acid-stressed E. coli O157:H7. Letters in Applied Microbiology 32, 312-315.

Karmali, M.A., Gannon, V., \& Sargeant, J.M. (2010). Verocytotoxin-producing Escherichia coli (VTEC). Veterinary Microbiology, 140, 360-370.

Kasrazadeh, M. \& Genigeorgis, C. (1995). Potential growth and control of Escherichia. coli O157:H7 in soft hispanic type cheese. International Journal of Food Microbiology 25, 289300.

Kaur, J., Ledward, D.A., Park, R.W.A. \& Robson, R.L. (1998). Factors affecting the heat resistance of Escherichia coli O157:H7. Letters in Applied Microbiology 26, 325-330.

Kenney, S.J. \& Beuchat, L.R. (2002). Survival of Escherichia coli O157:H7 and Salmonella Muenchen on apples as affected by application of commercial fruit waxes. International Journal of Food Microbiology 77, 223-231.

Kijima-Tanaka, M., Ishihara, K., Kojima, A., Morioka, A., Nagata, R., Kawanishi, M., Nakazawa, M., Tamura, Y. \&

\section{Health Sciences}


Takahashi, T. (2005). A national surveillance of Shiga toxinproducing Escherichia coli in food-producing animals in Japan. Journal of Veterinary Medicine Series 52, 230-237.

Kim, H.O., Park, S.W. \& Park, H.D. (2004). Inactivation of Escherichia coli O157:H7 by cinnamic aldehyde purified from Cinnamomum cassia shoot. Food Microbiology 21, 105-110.

Koseki, S., Yoshida, K., Kamitani, Y., Isobe, S. \& Itoh, K. (2004). Effect of mild heat pre-treatment with alkaline electrolyzed water on the efficacy of acidic electrolyzed water against Escherichia coli O157:H7 and Salmonella on lettuce. Food Microbiology $21,559-566$.

Leyer, G.J., Wang, L.L. \& Johnson, E.A. (1995). Acid adaptation of Escherichia. coli O157:H7 increases survival in acidic foods. Applied and Environmental Microbiology 61, 37525755.

Lopez-Galvez, F., Allende, A., Selma, M.V. \& Gil, M.I. (2009). Prevention of Escherichia coli cross-contamination by different commercial sanitizers during washing of fresh-cut lettuce. International Journal of Food Microbiology 133, 167-171.

Magwira, C.A., Gashe, B.A. \& Collison, E.K. (2005). Prevalence and antibiotic resistance profiles of Escherichia coli O157:H7 in beef products from retail outlets in Gaborone, Botswana. Journal of Food Protection 68, 403-406.

\section{Health Sciences}


Mahmoud, B.S.M. (2010). Effects of X-ray radiation on Escherichia coli O157:H7, Listeria monocytogenes, Salmonella enterica and Shigella flexneri inoculated on shredded iceberg lettuce. Food Microbiology 27, 109-114.

Marek, P., Nair, M.K.M., Hoagland, T. \& Venkitanarayanan, K. (2004). Survival and growth characteristics of Escherichia coli O157:H7 in pasteurized and unpasteurized cheddar cheese whey. International Journal of Food Microbiology 94, 1-7.

Marshall, K.M., Niebuhr, S.E., Acuff, G.R., Lucia, L.M. \& Dickson, J.S. (2005). Identification of Escherichia coli O157:H7 meat processing indicators for fresh meat through comparison of the effects of selected antimicrobial interventions. Journal of Food Protection 68, 2580-2586.

Mead, P.S. \& Griffin, P.M. (1998). Escherichia coli O157:H7. Lancet 532, 1207-1212.

Mead, P.S., Slutsker, L., Dietz, V., McCaig, L.F., Bresee, J.S., Shapiro, C., Griffin, P.M. \& Tauxe, R.V. (1999). Food-related illness and death in the United States. Emerging Infectious Diseases 5, 607-625.

Muthukumarasamy P \& Holley RA. (2007) Survival of Escherichia coli O157:H7 in dry fermented sausages containing micro-encapsulated probiotic lactic acid bacteria. Food microbiology 24(1), 82-88

\section{Health Sciences}


Nastasijevic, I., Mitrovic, R. \& Buncich, S. (2009). The occurrence of Escherichia coli $\mathrm{O} 157$ in/on faeces, carcasses and fresh meats from cattle. Meat Science 82, 101-105.

Nastasijevicl, I., Mitrovicl, R., \& Buncic, S. (2008). Occurrence of Escherichia coli O157 on hides of slaughtered cattle. Letters in Applied Microbiology, 46, 126-131.

No, H.K., Meyers, S.P., Prinyawiwatkul, W. \& Xu, Z. (2007). Applications of chitosan for improvement of quality and shelf life of foods: A review. Journal of Food Science, 72, R87R100.

Oliver, C.E., Magelky, B.K., Bauer, M.L., Cheng,F.C., Caton, J.S., Hakk, H., Larsen, G.L., Anderson, R.C \& Smith, D.J. (2008). Fate of chlorate present in cattle wastes and its impact on Salmonella typhimurium and E. coli O157. Journal of Agricultural and Food Chemistry 56, 6573-6583.

Pathanibul, P., Taylor, T.M., Davidson, P.M. \& Harte, F. (2009). Inactivation of Escherichia coli and Listeria innocua in apple and carrot juices using high pressure homogenization and nisin. International Journal of Food Microbiology 129, 316-320.

Rahal, E.A; kazzi N; Farahj, N and Matar, G.M. (2012). Escherichia O157:H7-Clinical aspects and novel treatment approaches. Frontiers in Cellular and Infection Microbiology 138, 17.

\section{Health Sciences}


Rasooly, R., \& Do, P.M. (2010). Shiga toxin Stx2 is heatstable and not inactivated by pasteurization. International Journal of Food Microbiology 136, 290-294.

Raybaudi-Massilia, R.M., Mosqueda-Melgar, J., SolivaFortuny, R. \& Martin-Belloso, O. (2009). Control of pathogenic and spoilage microorganisms in fresh-cut fruits and fruit juices by traditional and alternative natural antimicrobials. Comprehensive Reviews in Food Science and Food Safety 8, 157-180.

Reinstein, S., Fox, J.T., Shi, X., Alam, M.J., Renter, D.G. \& Nagaraja, T.G. (2009). Prevalence of Escherichia coli O157:H7 in organically and naturally raised beef cattle. Applied and Environmental Microbiology 75, 5421-5423.

Reitsma, C.J. \& Henning, D.R. (1996). Survival of enterohemorrhagic Escherichia coli O157:H7 during the manufacture and curing of cheddar cheese. Journal of Food Protection 59, 460-464.

Rhoades, J.R., Duffy, G. \& Koutsoumanis, K. (2009). Prevalence and concentration of verocytotoxigenic Escherichia coli, Salmonella enterica and Listeria monocytogenes in the beef production chain: A review. Food Microbiology 26, 357-376.

Schets, F.M., During, M., Italiaander, R., Heijnen, L., Rutjes, S.A., van der Zwaluw, W.K. \& Husman, A.M.D. (2005). Escherichia coli O157:H7 in drinking water from private water supplies in the Netherlands. Water Research 39, 4485-4493.

\section{Health Sciences}


Selma, M.V., Ibanez, A.M., Allende, A., Cantwell, M. \& Suslow, T. (2008). Effect of gaseous ozone and hot water on microbial and sensory quality of cantaloupe and potential transference of Escherichia coli O157:H7 during cutting. Food Microbiology 25, 162-168.

Silagyi, K., Kim, S., Lo, Y.M. \& Wei, C. (2009). Production of biofilm and quorum sensing by Escherichia coli O157:H7 and its transfer from contact surfaces to meat, poultry, ready-to-eat deli, and produce products. Food Microbiology 26, 514-519.

Soon, J.M., Chadd, S.A., \& Baines, R.N. (2011). Escherichia coli $\mathrm{O} 157$ in beef cattle: On farm contamination and preslaughter control method. Animal Health Research Reviews 12, 197-211.

Thomas, D.E. \& Elliott, E. J. (2013).Interventions for preventing diarrhea-associated hemolytic uremic syndrome: systematic review. BMC Public Health 13:799

http://www.biomedcentral.com/1471-2458/13/799

Voitoux, E., Lafarge, V., Collette, C. \& Lombard, B. (2002). Applicability of the draft standard method for the detection of Escherichia coli $\mathrm{O} 157$ in dairy products. International Journal of Food Microbiology 77, 213-221.

Wilks, S.A., Michels, H. \& Keevil, C.W. (2005). The survival of Escherichia coli $\mathrm{O} 157$ on a range of metal surfaces. International Journal of Food Microbiology 105, 445-454.

\section{Health Sciences}


Williams, A.P., Avery, L.M., Killham, K. \& Jones, D.L. (2005). Persistence of Escherichia coli O157 on farm surfaces under different environmental conditions. Journal of Applied Microbiology 98, 1075-1083. 